Simon Malmenvall

\title{
Onkraj geografskih in kulturnih meja: podoba "drugega» v staroruskem potopisu na ozadju katoliško-pravoslavnih odnosov
}

\section{Transcending Geographical and Cultural Borders: Image of the "Other" in the Rus' Travel Diary on the Background of Catholic-East Orthodox Relations}

Povz̧etek: Članek temelji na vzhodnoslovanskem potopisu z naslovom Življenje in romanje Danijela, igumana z Ruske zemlje, sestavljenem na začetku 12. stoletja. Danijelovo Romanje se umešča v začetno obdobje frankovske vladavine nad Palestino in pomeni najzgodnejši znani potopis vzhodnoslovanske srednjeveške literature. Obravnavano besedilo med drugim pričuje o Danijelovi podobi o samem sebi in o njegovem dojemanju »drugega«, ki zadeva predvsem katoliško-pravoslavne odnose v Jeruzalemskem kraljestvu. V skladu z opravljeno zgodovinsko in teološko analizo Romanja je katoliško-pravoslavne odnose v Jeruzalemskem kraljestvu mogoče opredeliti kot dvoumne: po eni strani je očitna jasna ločitev med "pravovernimi« in »Latinci«, po drugi pa je opazno strpno sobivanje pri ohranjanju spomina na kraje, povezane z biblijskimi dogodki. Na tej podlagi je Danijelovo Romanje primerjano s političnimi in kulturnimi okoliščinami v takratni Kijevski Rusiji, ki so pogojevale odnos staroruske elite do katoliške Cerkve. Tudi v tem primeru je mogoče opaziti dvoumno stanje: na deklarativni ravni polemični spisi kijevskih metropolitov pričujejo o negativnem stališču do »latinskih herezij«, po drugi strani pa odločitve staroruskih knezov potrjujejo njihovo pragmatično voljo po sodelovanju s sosednjimi katoliškimi političnimi tvorbami (Švedska, Poljska, Ogrska) pri oblikovanju dinastičnih porok in vojaških zavezništev.

Ključne besede: katoliško-pravoslavni odnosi, Stara Rusija, Jeruzalemsko kraljestvo, srednjeveška romanja, transkulturnost

Abstract: This article is based on the East Slavic travel diary titled Life and Pilgrimage of Daniel, Hegumen of the Land of Rus' written at the beginning of the 12th century. Daniel's Pilgrimage is placed within the initial period of the Frankish rule over Palestine and represents the earliest known travel diary in the East Slavic medieval literature. The text discussed, among other things, brings the testimony about Daniel's self-image and his perception of the »other concern- 
ing mainly the Catholic-East Orthodox relations in the Kingdom of Jerusalem. According to the historical and theological analysis of the Pilgrimage, the Catholic-East Orthodox relations in the Kingdom of Jerusalem can be defined as ambiguous: on the one hand, a clear distinction between the "Orthodox" and "Latins" is obvious, while, on the other, a tolerant coexistence in preserving the memory of the places connected with the Biblical events is noticeable. On this basis, Daniel's Pilgrimage is compared to the political and cultural circumstances in the Kievan Rus' of the time conditioning the attitude of the Rus' elite towards the Catholic Church. In this case, again, an ambiguous situation can be seen: on a declarative level, the polemical writings of the Kievan metropolitans testify about a negative position on the "Latin heresies"; on the other hand, decisions of the Rus' princes confirm their pragmatic willingness to cooperate with the neighboring Catholic polities (Sweden, Poland, Hungary) in forming dynastic marriages and military alliances.

Keywords: Catholic-East Orthodox relations, Rus', Kingdom of Jerusalem, medieval pilgrimages, transculturality

\section{Opredelitev teme in teoretični okvir}

Članek temelji na vzhodnoslovanskem potopisu z naslovom Življenje in romanje Danijela, igumana z Ruske zem/ji ${ }^{4}$ sestavljenem v prvem desetletju 12. stoletja, v času jeruzalemskega kralja Balduina I. (1100-1118). Danijelovo Romanje se umešča $v$ začetno obdobje frankovske vladavine nad Palestino in pomeni najzgodnejši znani potopis vzhodnoslovanske srednjeveške literature. Danijelovo besedilo glede na zakonitosti žanra romarskega potopisa največ pozornosti namenja duhovnim razsežnostim romanja, $v$ danem primeru simbolnemu vstopu Kijevske Rusije v proces zgodovine odrešenja ${ }^{5}$ na ozemlju Svete dežele, s preseganjem svojih lastnih geografskih in kulturnih meja. Kljub temu je eno pomembnejših razsežnosti obravnavanega besedila mogoče prepoznati v pričevanju o Danijelovi podobi o samem sebi in o njegovem dojemanju »drugega", ki zadeva predvsem katoliško-pravoslavne (»latinsko-grške«) ${ }^{6}$ odnose v Jeruzalemskem kraljestvu.

4 Ker besedilo Romanja v slovenščino še ni prevedeno, je za prevod izbranih odlomkov iz cerkvenoslovanskega izvirnika poskrbel avtor članka.

5 Osnovi pregled teološkega pojmovanja zgodovine kot zgodovine odrešenja: Malmenvall 2018a. O primerih odsevanja zgodovine odrešenja v »patriotsko konstitutivnih « pripovednih zgodovinskih virih Kijevske Rusije: Ryčka 2005; Ostrowski 2011; Malmenvall 2015; 2017a; 2017b.

6 Iguman Danijel pripadnike svoje lastne verske skupnosti imenuje »pravoverni« (csl. правовьрьнии) ali "pravoslavni« (csl. православнии), svojega konfesionalnega »drugega « pa »Latinci« (csl. латинянь) ali »Franki« (csl. фрязи) (Prohorov 2007a, 116; 126; 128). Ob zavedanju terminološke večplastnosti zaradi jezikovnih, zgodovinskih in teoloških dejavnikov sta v tem članku v prid večji razlagalni jasnosti uporabljena uveljavljena pojma "pravoslavni« in »katoliški«. Njuna raba v kontekstu obravnavanega časa in prostora resda še ne označuje izostrenih doktrinarnih in drugih razlik med (prihodnjim) katoliškim in pravoslavnim krščanstvom - pomembni razkol med zahodno (rimsko, "latinsko«) in vzhodno (bizantinsko, "grško«) polovico nekdaj enotne krščanske Cerkve se je zgodil leta 1054, njegove (politične) 
Prav temu je posvečen ta članek. Danijelovo Romanje dodatno osvetljuje primerjava s političnimi in kulturnimi okoliščinami v takratni Kijevski Rusiji, ki so pogojevale odnos staroruske elite do katoliške Cerkve. Tu so na deklarativni ravni ključni polemični »protilatinski« spisi kijevskih metropolitov grškega oziroma bizantinskega izvora, na politični ravni pa odločitve staroruskih knezov, ki potrjujejo njihovo pragmatično voljo po sodelovanju s sosednjimi katoliškimi političnimi tvorbami (Švedska, Poljska, Ogrska) pri oblikovanju dinastičnih porok in vojaških zavezništev.

Teoretični okvir, na katerega pristaja avtor tega članka, izhaja iz prepričanja o situacijsko povzročenem vzpostavljanju konfesionalnih, etničnih in drugih identitetnih kategorij v srednjeveških pripovednih besedilih. Govorimo o mehanizmu oblikovanja predstav o sebi in svetu (o domačem in tujem okolju), ki se pri srednjeveškem piscu poraja na podlagi »srečanja z »drugim«. To je mogoče vzporejati s temeljnim načelom ruske semiotične kulturološke šole oziroma njenega glavnega predstavnika, Jurija Lotmana (1922-1993), naslednika izvorno jezikoslovne strukturalistične paradigme, ki v središče svoje teorije (2006) postavlja pojma odnosa in primerjave: prepoznavanje in vrednotenje kakršnegakoli elementa kulture, od filozofsko-teoloških sistemov in družbenih identitetnih kategorij do posameznega umetniškega dela, vselej potekata v odnosu do »drugega«; vsak element kulture svoj obstoj dobiva šele v »srečanju« z njim, brez njega sebe ne more dojemati kot nečesa samostojnega, kot nečesa, kar se od »drugega« razlikuje. To potrjujejo tudi sklepi nemškega zgodovinarja Hagena Schulzeja (19432014), ki na področju preučevanja etničnih kategorij v srednjem veku trdi, da te kategorije po eni strani niso imele odločilnega pomena pri oblikovanju takratnega razumevanja stvarnosti, po drugi strani pa so v zgodovinskih virih opazne takrat, kadar so bili nekateri posamezniki ali skupine odvisni od »srečevanja« (bodisi miroljubnega ali sovražnega) z »drugim«. Etnične kategorije so tako situacijsko ozaveščale ali na novo ustvarjale kolektivno "samobitnost « na podlagi (domnevne) jezikovne, rodovne ali geografsko-naselitvene bližine pripadnikov neke določene skupine. (2003, 13-100) V podobni smeri razmišlja tudi pomemben del sodobne postmoderne teologije, ki v ospredje postavlja pojme, kakor denimo »(medkulturni) dialog « in »srečanje z drugim«, Boga samega pa razume kot počelo dialoškosti, kot „Drugega « z veliko začetnico. ${ }^{7}$

Obravnavani potopis je v luči zgoraj pojasnjenega zanimiv zlasti zato, ker po času svojega nastanka in po zvrstnih značilnostih zaokroža staroruske pripovedne vire s prehoda iz 11. v 12. stoletje, ki se posvečajo grajenju svoje lastne podobe na novo pokristjanjene Kijevske Rusije na podlagi njene nedavne zgodovinske izkušnje in umestitve v okvir zgodovine odrešenja kot enakovrednega dela takratnega krščanskega sveta. Danijelov potopis staroruski zgodovinski izkušnji pripisuje neposredni stik s Sveto deželo in s tamkajšnjo biblijsko zgodovino, s tem pa

posledice so očitneje prišle na dan šele na začetku 13. stoletja, po križarski oplenitvi Konstantinopla leta 1204. O omenjenih terminoloških vprašanjih in njihovih pogojnih rešitvah: Meyendorff 1983, 97-99; 212-213; Chadwick 2003, 1; 233-237; Siecienski 2013, 3-15.

7 Podobno teoretično izhodišče je mogoče opaziti tudi pri (nekaterih) sodobnih slovenskih teologih: Bogataj 2018, 960-961; 967-968; Osredkar 2018; 2016a, 269-275; 2016b; Klun 2016. 
vsesplošno krščansko naravo. Obravnavano besedilo je obenem del v srednjem veku družbeno cenjenega rojstva romanj: $v$ danem primeru romati pomeni, iti "onkraj« sebe, »onkraj« znanega okolja; predvideva namreč srečanje z »drugim«, ki omogoča oblikovanje jasnejše podobe o sebi in o zgodovini. Romati pomeni, zapustiti svoj prostor in čas, odpreti se delovanju Boga in razširiti svoje obzorje s spoznanjem novih dežel. Govorimo o preseganju svoje lastne določenosti in o pot $\mathrm{k}$ notranji preobrazbi, ko večno vstopa $v$ časno in ga povzdiguje v prizorišče "srečevanja« med Bogom in človekom.

\section{Zgodovinski in literarni kontekst}

$\mathrm{V}$ prvi polovici 12. stoletja je med katoliškimi vojskovodji, ki so po večini izhajali z ozemlja današnje Francije, izstopal kralj Balduin I. (1100-1118), vladar Jeruzalemskega kraljestva, ustanovljenega po prvi križarski osvojitvi Jeruzalema. Balduin je zavzemal tudi položaj neuradnega voditelja »latinskih" državnih tvorb, ki so se raztezale v obalnem pasu od Antiohije oziroma Bizantinskega cesarstva na severu do Rdečega morja oziroma Egipta na jugu. (MacEvitt 2008, 5-7) Večino prebivalstva Balduinove Palestine so sestavljali arabsko, sirsko in grško govoreči pravoslavni kristjani, imenovani tudi melkiti, med krščanskim prebivalstvom pa so pomemben delež tvorili tudi monofizitski kristjani, zlasti tako imenovani sirski jakobiti in Armenci (7-9; 110). Vladarjeva politika do nekatoliških kristjanov je bila dvojna: številčno manjšinski »latinski« Cerkvi je podelil višji pravni status (npr. deklarativna nadrejenost katoliških škofov nekatoliškim), medtem ko je istočasno gojil strpnost do drugih kristjanov, ki so lahko ohranili svoje škofe, živeli po svojih običajih in bili deležni kraljevih sredstev za obnavljanje starih in za gradnjo novih cerkva (Runciman 1990, 4; 86-87; 100-101; Riley-Smith 2005, 53-55; 61-63; 66-69; 72; 75; 83; MacEvitt 2008, 21; 134). Strpnost med katoliškimi in nekatoliškimi kristjani je bila posebno očitna pri romarjih, ki so iz različnih evropskih in sredozemskih dežel prihajali v Palestino - vzhodnokrščanski romarji v primerjavi s katoliškimi niso doživljali neenake obravnave (MacEvitt 2008, 132-133; 135).

Besedilo Življenje in romanje Danijela, igumana z Ruske zemlje (csl. Жumьe u хоженье Даниила, русьскыя земли игумена), sestavljeno v prvem desetletju 12. stoletja, velja za najstarejši in v naslednjih stoletjih pogosto prepisovani romarski potopis kijevskega obdobja vzhodnoslovanske srednjeveške kulture (Seemann 1970, VII; IX; XXXI; XLI-XLIII; XLIV; Podskal'ski 1996, 318; 321; Gardzaniti 2007, 274; Prohorov 2007b, 10; 12). Na podlagi odlomka v prvih vrsticah potopisa (Prohorov 2007a, 16) je mogoče sklepati, da je Danijelovo potovanje po Sveti deželi trajalo šestnajst mesecev. Danijel v Romanju izrecno ne navaja letnice začetka ali letnice konca svojega potovanja, iz posrednih omemb in splošnih okoliščin pa je jasno, da je potekalo v času frankovskih vpadov na sirsko ozemlje med letoma 1104 in 1108 pod jeruzalemskim kraljem Balduinom I. (Ščapov 2003, 85; Prohorov 2007a, 92). Kar je o Danijelu znanega, najdemo edinole v njegovem potopisu (Seemann 1970, VII; Garzaniti 1991, 19). Iz Romanja je mogoče ugotoviti zgolj 
to, da je bil Danijel iguman oziroma predstojnik nekega nenavedenega samostana na ozemlju Kijevske Rusije, na podlagi posrednih omemb (npr. primerjava reke Jordan z reko Snov, omemba kneza Olega Svjatoslaviča) pa se ponuja domneva, da je Danijel izhajal iz mesta Černigov ali njegove okolice severovzhodno od Kijeva (Prohorov 2007a, 20; 137; 2007b, 10).

Med izvirno vzhodnoslovansko srednjeveško literaturo so prevladovala dela zgodovinske narave, ki jih je mogoče uvrstiti v letopisno ali hagiografsko zvrst. V isto skupino, posvečeno zgodovinsko-teološkim vidikom stvarnosti, sodijo tudi romarski potopisi, ki navadno obravnavajo Palestino, meniško goro Atos ali Konstantinopel. (Seemann 1976, 11-13; 76-77; 139; 144; 191; Podskal'ski 1996, 318) Romanje v prvi vrsti pomeni osebno pričevanje nad Palestino navdušenega potopisca in hkrati duhovno izoblikovajoče branje za tiste, ki Svete dežele (morda) nikoli ne bodo obiskali (Seemann 1976, 37-38; 45; Podskal'ski 1996, 324; Gardzaniti 2007, 323-324; 327). Romanje sestavljajo trije geografsko in časovno zaokroženi pripovedni sklopi: pot v Sveto deželo do Jeruzalema, opis palestinskih mest in nato vrnitev v Jeruzalem; opis poti po Galileji; pričevanje o čudežu velikonočne luči v Jeruzalemu. V Danijelovem potopisu je največ besed namenjenih Jeruzalemu, poleg tega se celotna obravnava Svete dežele začenja in končuje prav v tem mestu - to je središče, okrog katerega se zgošča celotno potovanje. Jedro Romanja tvori natančno opisovanje svetih krajev, različnih stavb (zlasti cerkva) in relikvij, ki ga spremljajo potopiščevi prvoosebni komentarji in povzemanje biblijskih in legendarno-apokrifnih zgodb, zadevajočih opisovane svete kraje. (Seemann 1970, XII; XVIII; Garzaniti 1991, 21-24; 30-31; Gardzaniti 2007, 277-278; 296) Ko Danijel piše o Sveti deželi, skoraj nič ne poroča o življenju krajevnega prebivalstva, niti ga posebej ne zanimajo tamkajšnje družbenopolitične razmere. V tem kontekstu je pomenljivo, da med vsemi prebivalci Palestine, razen kralja Balduina, nikogar ne navaja poimensko. Danijela zanima predvsem ubeseditev njegove lastne soudeležbe v »svetem prostoru«, pričujočem o »božji moči«, ki se razodeva skozi zgodovino. V skladu z obravnavanim potopisom se kot posvečena kažejo vsa zgodovinska obdobja - od stvarjenja sveta in prvega človeka Adama, čigar lobanja po pričevanju Romanja leži ob vznožju Golgote (Prohorov 2007a, 30), pa vse do Danijelove sodobnosti, ko mu je po »božji milosti« v imenu celotne »Ruske zemlje» uspelo postaviti svetilko na Kristusov grob $(122 ; 124)$.

V Romanju pripoved poteka na dveh časovnih ravneh. Prvo raven tvori linearni čas, odvisen od zemeljskih zakonov spreminjanja in minevanja. Raven linearnega časa se, denimo, kaže skozi omembe roparskih napadov muslimanskih sosedov $(24 ; 72 ; 82 ; 96 ; 112 ; 118)$ na romarje in na krščanske prebivalce. Drugo časovno raven pomenijo osebna pričevanja, ki poudarjajo fizično navzočnost Danijela in njegovih tovarišev znotraj neke določene resničnosti zgodovine odrešenja. Tu je vredno izpostaviti naslednji odlomek: »lz te skale priteka izvir in ta kopel je čudežna, sama se je pojavila, saj jo je ustvaril Bog. V tej kopeli se je kopal sam Kristus s svojimi učenci. In do današnjega dne je znano to mesto, kjer je Kristus sedel na kamnu. Tu smo se kopali tudi mi nevredni grešniki.« $(96 ; 98)$ Tako sprva dobesedno zemeljsko pričevanje o kopanju pri izviru postane pričevanje o »nadnaravni« 
resničnosti, tukaj o podoživljanju Kristusovega življenja. Ko se Danijelova beseda dotika svetih krajev, zemeljski čas izgublja svojo neizbežno moč, posamezni sveti kraj pa ohranja svojo simbolno stalnost. $S$ tem Danijelovo pričevanje postane »premično « oziroma sega »onkraj časa - prehaja v preteklost, iz preteklosti pa v večnost, od koder se vrača v svoj lastni čas. Danijel se tako ne premika le v smislu fizičnega potovanja, temveč »potuje« tudi v času in se dotika večnosti.

\section{Danijelov "drugi« in vzpostavljanje svoje lastne (samo)podobe}

Tematika katoliške skupnosti kot Danijelovega glavnega »drugega« se obravnavanega potopisa neposredno dotika ob upoštevanju naslednjih dejstev: potopisec iz pravoslavnega okolja je Palestino obiskal za časa katoliškega Jeruzalemskega kraljestva in je lahko zato do katolištva vzpostavil odnos v prostoru,v katerem je katolištvo pomenilo družbeno vodilno silo; Danijel se je tudi osebno srečal s kraljem Balduinom, oznako za romarja ("palomnik«, csl. паломникъ) pa prevzel po latinski besedi "palmarius«. ${ }^{8}$

Iguman Danijel kralja Balduina prikazuje v izrazito svetli luči. V Romanju piše, da ga je Balduin »zelo dobro poznal« in ga imel »zelo rad« (122). Prav tako ga označuje za »krepostnega moža in zelo ponižnega in niti malo prevzetnega« (122). Balduinova krepost se je po Danijelovem pričevanju posebej izrazila, ko je njega in njegove tovariše »radostno pozval, naj gredo z njim « do Tiberijskega morja (92). Tako je igumanova skupina tiste "strašne kraje«, ki so jih pogosto prizadeli vpadi muslimanskih roparjev in vojsk iz Sirije, prepotovala »brez strahu in zločinov« ob zaščiti Balduinove vojske (92). To je Danijelu in njegovim sopotnikom tudi omogočilo, da so obiskali svete kraje, povezane s Kristusovim zemeljskim življenjem - denimo Nazaret, goro Tabor in Kano Galilejsko. Zdi se, da je bila naklonjenost obojestranska, konfesionalne razlike pa naj ne bi igrale pomembne vloge. $V$ podobno naklonjenem duhu je napisan tudi odlomek o Danijelovem obisku Nazareta, kjer si je skupaj s svojimi tovariši ogledal ostanke hiše sv. Jožefa, Marijinega ženina. Ko potopisec pripoveduje o tem dogajanju, nedvoumno hvali gostoljubnost katoliške skupnosti - označuje jo z izrazom »Franki« (csl. фрязи) - in njeno skrb za omenjeni sveti kraj.

»In tu [v Nazaretu] je bila Jožefova hiša, kjer je ta sveta votlina. /... / In tu je cerkev, zgrajena nad to sveto votlino, posvečena svetemu oznanjenju. Ta kraj je bil nekoč zapuščen, sedaj pa so ta kraj obnovili Franki in ga dobro uredili. In tu je latinski škof, zelo bogat, in ta vlada nad tem svetim krajem. In počastili so nas $z$ dobro pijačo in jedačo in vsem [drugim]. In v tem mestu smo prespali eno noč. In ko smo si dobro odpočili in zjutraj vstali, smo šli v to cerkev in se poklonili temu svetemu kraju." (116)

8 Ta izraz označuje človeka, ki je obiskal Sveto deželo in se domov vrnil s palmovimi vejami kot vidnim znakom opravljenega romanja. Kakor sama beseda "palmarius « tudi običaj prinašanja palmovih vej izhaja iz zahodnokrščanskega sveta. (Nazarenko 2001, 620; 626-627; Riley-Smith 2005, 44-45) 
Najočitnejši izraz dobrih ali vsaj strpnih odnosov med katoliško in pravoslavno skupnostjo na ozemlju Palestine prinaša pričevanje o skupnem obhajanju velike noči na skupno priznanem najsvetejšem kraju, v baziliki nad božjim grobom, ob navzočnosti kralja Balduina. Tu potopisec znova izpostavi Balduinovo prijaznost, saj mu je dovolil postaviti svetilko na sam božji grob in ga med vigilijo poslal na ugledno mesto na enem od korov tik nad vrati v božji grob, od koder je lahko pozorno spremljal dogajanje. (126; 128)

„Takrat sem /... / na tisti [veliki] petek ob prvi uri podnevi šel k onemu knezu Balduinu in se mu poklonil do tal. On pa /... / me je poklical k sebi z ljubeznijo in mi rekel: sKaj želiš, ruski iguman? ‘ Dobro me je namreč poznal in zelo me je imel rad. /... / Jaz pa sem mu rekel: ıMoj knez, moj gospod! Prosim te: zavoljo Boga in ruskih knezov mi dovoli, da tudi sam postavim svojo svetilko na sveti grob v imenu celotne Ruske zemlje! ‘ Takrat mi je z resnostjo in ljubeznijo dovolil postaviti svetilko na Gospodovem grobu. /... / In s svojima grešnima rokama sem postavil [svetilko] k nogam, kjer so ležale prečiste noge našega Gospoda Jezusa Kristusa. Pri glavi namreč stoji grška svetilka, na prsih pa je bila postavljena svetilka [lavre] sv. Save in vseh samostanov. /... / In takrat [/pri vigiliji v soboto zvečer] so se prižgale te tri svetilke.« $(122 ; 124)$

Kljub skupnemu obhajanju velikonočne vigilije Danijel jasno uvede razliko med "Latinci« (csl. латинянб) oziroma katoličani na eni strani in pravoslavnimi na drugi, ki jih imenuje z izrazom »pravoverni« (csl. правовьрьнии), s katerim poudarja, da prava krščanska vera ni ohranjena v katoliški, temveč v pravoslavni Cerkvi. Razliko med »pravovernimi« in »Latinci« dodatno podkrepi z opazko, s katero smeši petje katoliških duhovnikov. Trdi namreč, da so pravoslavni popje (csl. попы) in menihi večernice nad božjim grobom »peli«, "Latinci« pa so pri velikem oltarju „vreščali« (csl. верещали). Tu je pomenljiv naslednji odlomek:

»In knez [/kralj Balduin] je igumanu [lavre] sv. Save naročil, naj s svojimi menihi in s pravovernimi popi stoji nad grobom. Mene /... / je dal postaviti visoko nad samimi vrati groba proti velikemu oltarju, da sem lahko gledal v grobna vrata. Latinski popje so stali pri velikem oltarju. In ko je prišla osma ura dneva, so začeli pravoverni popje in menihi in vsi duhovni možje peti večernice nad grobom. Tu so bili mnogi puščavniki. Latinci pa so pri velikem oltarju začeli vreščati po svoje. In tako so vsi peli, jaz pa sem tam stal in pozorno gledal h grobnim vratom.« $(126 ; 128)$

Razlike v verskem nauku in praksi med katoliškimi in pravoslavnimi kristjani so v potopisu izpostavljene le dvakrat. Prvič so izpostavljene v kontekstu duhovne interpretacije pomena gore Tabor, v kateri je mogoče najti tudi prikrito in v potopiščevem času aktualno polemično ost, usmerjeno proti katolikom, ki zadeva njihovo liturgično prakso. Govorimo o kritiki katoliške rabe nekvašenega kruha pri evharistiji in s tem o potrjevanju pravilnosti pravoslavne prakse, ki zapoveduje rabo kvašenega kruha. (Gardzaniti 2007, 293; Prohorov 2007a, 112, 158) Drugič 
so izpostavljene v kontekstu čudeža z »nebeškim ognjem « na velikonočno vigilijo v baziliki Kristusovega vstajenja. Danijel v svojem potopisu kljub pozitivnemu prikazovanju Balduina in Frankov daje jasno vedeti, da je pravoslavna vera zanj edina prava. Ob pripovedi o vsakoletnem čudežu samodejnega prižiga ognja med velikonočno vigilijo v baziliki Kristusovega vstajenja resda res izreka pohvalo Balduinu, da mu je dovolil obesiti in prižgati svetilko ob božjem grobu. Toda istočasno izpostavlja, da je na svoje lastne oči videl, kako so se pri Kristusovem grobu prižgale grške svetilke in skupaj z njimi svetilka, ki jo je v imenu celotne Stare Rusije postavil on sam, medtem ko so katoliške ostale ugasnjene. (Prohorov 2007a, 124) To je po Danijelovem prepričanju čudežna potrditev pravovernosti pravoslavne Cerkve in okrnjenosti katoliške. S tem potopisec vzpostavlja napetost med dvema vrstama obrambe krščanskih svetinj - med neposredno obrambo Palestine, ki jo opravljajo katoliški križarji, in duhovno obrambo čistosti krščanske vere, ki jo opravlja zgolj pravoslavna Cerkev.

Sestavni del in nekakšno zrcalno podobo opisanih krajev, stavb in relikvij Svete dežele kot potopiscu tujega okolja, vključno z obravnavo svojega katoliškega »drugega «, predstavlja Danijelovo vzpostavljanje odnosa do samega sebe in do svoje lastne domovine Kijevske Rusije. V tem pogledu je prav »srečanje« $\mathrm{z}$ »drugim«, ki ga prinaša romanje kot prehajanje »onkraj« sebe in spoznavanje dotlej neznanega, odločilnega pomena za oblikovanje jasnejše podobe o sebi. To je opazno že na začetku potopisa, ko Danijel bralcu sporoča, da je romanje opravil v vlogi igumana z »Ruske zemlje» (csl. русьска земля) (15). Sebe ne šteje za predstavnika nekega določenega kraja ali pokrajine, celo ne za pripadnika nekega določenega samostana, temveč se pred starorusko izobraženo javnostjo istoveti s svojo domovino, s celotno "Rusko zemljo « - ima se torej za predstavnika širšega geografsko-etničnega prostora, iz katerega izhaja. $V$ podobnem duhu na božji grob postavi svetilko "v imenu celotne Ruske zemlje" (122) in poudari: »Na nobenem svetem kraju nisem pozabil imen ruskih knezov in kneginj in njihovih otrok, škofov, igumanov, bojarjev in svojih duhovnih otrok. (132) Pomenljivo je, da med vsemi prebivalci Palestine, razen kralja Balduina, nikogar ne navaja poimensko, temveč omenja zgolj osebe, ki izvirajo iz Stare Rusije. Med temi omenja dva romarja po imenu Izjaslav Ivanovič in Gorodislav Mihajlovič Kašička (34; 130). Poimensko navaja tudi nekatere staroruske kneze, za katere je posebej molil ob postavitvi svetilke na Kristusov grob: Mihaela Svjatopolka, Vasilija Vladimirja, Davida Svjatoslaviča, Mihaela Olega, Pankracija Svjatoslava in Gleba Menskega (134). Danijelova pripadnost staroruski domovini je še bolj opazna ob upoštevanju njegovega cilja. Na božji grob je namreč položil svetilko »v imenu celotne Ruske zemlje« in ne kake vzhodnoslovanske kneževine takratnega časa, da bi tako izrazil duhovno navzočnost Kijevske Rusije v Palestini. S postavitvijo svetilke na božji grob, osrednji in najsvetejši kraj celotnega krščanskega sveta, je bila Kijevska Rusija simbolno pridružena posvečenemu času in prostoru, zgoščenemu v Sveti deželi. S tem ko je Danijelu "po božji milosti« uspelo postaviti svetilko »v imenu celotne Ruske zemlje« skupaj z "grško" svetilko in s svetilko lavre sv. Save, se je Kijevska Rusija simbolno pridružila tistim skupnostim krščanskega sveta, ki jim je bilo zaradi njihovega ugleda 
dovoljeno redno postavljati svetilke na božji grob. Kijevska Rusija je s svojim neposrednim stikom s Sveto deželo in z božjim grobom postala duhovno enakovredni in polnopravni del krščanskega sveta, vključenega v zgodovino odrešenja. Glede na druge pomembnejše versko in patriotsko zaznamovane vire staroruskega literarnega izročila med sredino 11. in sredino 12. stoletja - Pripoved o minulih letih (letopis), Beseda o postavi in milosti (pridiga), Branje o Borisu in Glebu (hagiografija) - je mogoče skleniti, da Romanje doda utemeljitev dokončne vključitve Stare Rusije v kontekst teološke interpretacije svetovne zgodovine. Drugače od drugih naštetih virov je geografsko, zgodovinsko in teološko obzorje Romanja širše, saj starorusko izkušnjo nadgrajuje z umestitvijo v univerzalni krščanski okvir Svete dežele, v kateri so potekali vsi ključni biblijski dogodki in v kateri se je po Jezusu Kristusu zgodilo odrešenje človeštva.

\section{Staroruski odnos do katoliškega sveta na prehodu iz 11. v 12. stoletje}

V precejšnji meri naklonjenega in obenem dvoumnega odnosa do katoliške skupnosti, kakor se kaže v Danijelovem Romanju, ni ustrezno razumeti kot nečesa osamljenega v obravnavanem potopisu. Smiselno ga je primerjati s političnimi in kulturnimi okoliščinami v takratni Kijevski Rusiji, ki so pogojevale odnos staroruske elite do katoliške Cerkve. Krščanstvo se je med vzhodnimi Slovani konec 10. stoletja kot državna vera uveljavilo z bizantinskim posredništvom. Kijevska metropolija, ki je od sredine 11 . stoletja dalje pokrivala celotno ozemlje Kijevske Rusije, je bila podrejena konstantinopelskemu patriarhu. Ta metropolija je med vsemi ozemeljskimi enotami konstantinopelske Cerkve po površini in po dohodkih zavzemala prvo mesto; položaj tamkajšnjega metropolita so navadno zasedali pripadniki najvišjih slojev bizantinske družbe iz krogov blizu cesarju ali patriarhu, to pa priča o tem, da je bila kijevska metropolija za Konstantinopel velikega pomena. (Malmenvall 2018b, 29-30; Senyk 1993, 298-301; Tachiaos 1988/1989, 430; 432433) Kljub temu je starorusko ozemlje na severu in na zahodu mejilo na katoliški svet in bilo z njim v nenehnem stiku. Staroruski deklarativni odnos do katoliškega krščanstva so v največji meri oblikovali kijevski metropoliti, ki so bili vse do sredine 13. stoletja skoraj izključno bizantinskega oziroma grškega izvora in so zastopali stališča in širili navade konstantinopelske Cerkve (Tachiaos 1988/1989, 431; 434; 440-442). V skrbi za ohranjanje pravovernosti so v drugi polovici 11 . in v prvi polovici 12. stoletja, neposredno po »velikem razkolu« med Rimom in Konstantinoplom leta 1054 torej, ${ }^{9}$ razvili posebno literarno zvrst polemičnih spisov proti različnim obrednim in disciplinskim praksam in doktrinarnim postavkam (»herezijam«), uveljavljenim v takratni katoliški Cerkvi. ${ }^{10}$ Med ponavljajočimi se očitki

9 Celovita študija o doktrinarnih in drugih razlikah in o odnosu med katoliško in pravoslavno Cerkvijo skozi zgodovino: Chadwick 2003.

10 Večina tovrstnih spisov, navadno prvotno sestavljenih v grščini in pozneje prevedenih v cerkveno slovanščino, je zbrana in komentirana v še vedno referenčnem delu: Popov 1875. 
»latinski« strani, v dobršni meri prevzetimi po pismih patriarha Fotija (857-867, 877-886) in Mihaela I. Kerularija (1043-1059), prevladujejo: dogmatična opredelitev izhajanja Svetega Duha iz "Očeta in Sina (Filioque), obhajanje evharistije z nekvašenim kruhom, obvezni celibat za nižjo duhovščino in nošenje prstana kot znamenja škofovske službe. Tem in podobnim očitkom se pridružuje svarilo pred druženjem in sklepanjem zakonskih zvez z "Latinci«. (Danilevskij 2018, 118120;123-124) Kijevska politična tvorba je tako na področju cerkvenih zadev ostajala zvesta pravoslavni veri, politične odločitve staroruskih knezov, denimo sklepanje dinastičnih porok in vojaških zavezništvih, pa so kazale na njihovo pragmatično voljo po sodelovanju s katoliškimi državami, zlasti s sosednjo Švedsko, Poljsko in Ogrsko (Senyk 1993, 298-301; 306).

Odsotnost centraliziranega sistema posvetne oblasti in potreba po misijonarskem utrjevanju vere med ljudstvom na (zgolj) deklarativno pokristjanjenem območju sta Kijevsko Rusijo v splošnem družbenem smislu precej bolj zbliževali s severno- in srednjeevropskimi državnimi tvorbami tistega časa kakor pa s centraliziranim in kulturno razvitim Bizantinskim cesarstvom. Zato je razumljivo, da je tudi življenje staroruske Cerkve v nekem smislu posnemalo zahodne zglede, denimo dajatve v obliki desetine, ki je bila verjetno prevzeta po zgledu takratne Poljske. (301) Pri tem nadalje ni mogoče zaobiti dejstva, da je bila velika večina v ohranjenih zgodovinskih virih izpričanih dinastičnih porok (okrog tri četrtine), $v$ katerih so bili udeleženi predstavniki in predstavnice vladajoče staroruske rodbine Rjurikovičev, med sredino 10. in sredino 12. stoletja sklenjenih prav s katoliškimi političnimi tvorbami zahodno od kijevske države, predvsem s Poljsko, z Ogrsko in s Švedsko, a tudi z Norveško, Dansko, Svetim rimskim cesarstvom, Francijo in z Anglijo. Kijevska Rusija je tako z diplomatskimi, z dinastičnimi in z vojaškimi sredstvi dejavno sooblikovala politično podobo takratne severne in srednje Evrope; tu so bile zaradi geografske bližine najživahnejše vezi med vzhodnoslovanskim ozemljem in Poljsko. (Raffensperger 2012, 47-48; 51-53) Od tod postane jasno, da se edinost v pravoslavni veri med Kijevsko Rusijo in Bizantinskim cesarstvom ni samodejno kazala v njuni politični prepletenosti. To je mogoče pojasniti tudi z načinom življenja staroruskih knezov, ki se je močno razlikoval od stanja v Bizancu. Člani bizantinskega cesarskega dvora so prebivali v Konstantinoplu in redko potovali, obkrožali so jih služabniki in uradniki, medtem ko so staroruski knezi oblast izvajali prek družinskih članov, imeli slabo razvito uradniško mrežo in bili pogosto na poti s svojim vojaškim spremstvom - to je vsaj do sredine 12 . stoletja veljalo tudi za politične tvorbe $v$ severni in srednji Evropi. Poleg tega so dinastične vezi z nedavno pokristjanjenimi "severnjaki«, med katere je sodil tudi vzhodnoslovanski prostor, v očeh bizantinske diplomacije veljale za neugledne in zato tudi redke. (51-53)

$\checkmark$ tem kontekstu je pomenljiva diplomatska misija kijevskega kneza Izjaslava Jaroslaviča (1054-1073, 1076-1078), moža Gertrude, hčere poljskega kralja Mieszka II. (1025-1034). Izjaslav je med letoma 1073 in 1075 med izgnanstvom v Svetem rimskem cesarstvu poslal svojega sina Jaropolka v Rim k papežu Gregorju VII. (10731085), da bi si pridobil njegovo podporo pri vnovičnem zavzetju kijevskega prestola. Papeževo podporo je dobil, kijevski prestol leta 1077 znova vojaško osvojil, a že 
naslednje leto umrl. Kljub pridobitvi papeževe podpore ohranjeni viri ne poročajo, da bi moral Izjaslav uradno prestopiti iz pravoslavja v katolištvo. Na tej podlagi je mogoče sklepati, da so kijevskega kneza vodili pragmatični in ne duhovno-konfesionalni razlogi. Ob upoštevanju takratnega katoliškega samorazumevanja papeške službe je mogoče predvidevati, da je Gregor VII. kijevsko metropolijo, ne glede na stvarne cerkvenopolitične razmere, vedno obravnaval kot sebi simbolno podrejeno, saj se je imel za voditelja vesoljne krščanske Cerkve. Od podpore Izjaslavu si je morda obetal poznejši - čeprav dejansko nikoli uresničeni - prodor latinske Cerkve na vzhodnoslovansko ozemlje. (306-308) Prav tako je pomenljiv zgled kijevskega metropolita loana/Janeza II. (1077-1089), avtorja pisma protipapežu Klementu III. (1080-1099) kot odgovora na pismo, v katerem ta protipapež Janezu predlaga združitev med katoliško in starorusko pravoslavno Cerkvijo pod pokroviteljstvom Rima. Kijevski metropolit je Klementov predlog zavrnil in ob tem navedel različne razloge za »odpadništvo« katoliške Cerkve. V svojem pismu Klementu je izrazil tudi negodovanje nad nekaterimi poimensko nenavedenimi staroruskimi knezi. Očital jim je poročanje z nevestami iz katoliških vladarskih rodbin in kot posledico tega njihovo versko mlačnost. Bal se je namreč, da bi politični stiki in zavezništva s katoliškimi političnimi tvorbami povzročili krhanje cerkvenih vezi s Konstantinoplom in sčasoma tudi podreditev papežu. (Levčenko 1956, 420-421; Senyk 1993, 317319; Podskal'ski 1996, 285-289) V okviru staroruske prakse poročanja s člani ali članicami katoliških vladarskih rodbin je nastalo tudi dopisovanje med kijevskim knezom Vladimirjem Monomahom (1113-1125) in kijevskim metropolitom Nikeforjem I. (1104-1121). Knez ga je spraševal o vsebini nesoglasij, ki so povzročila razkol med vzhodno in zahodno Cerkvijo, metropolit pa mu je pojasnil dvajset »krivd« katoliške strani. (Senyk 1993, 319; Podskal'ski 1996, 290-292)

Iz doslej predstavljenih okoliščin je »protilatinske» polemične spise ustrezno razumeti ne le kot učeni izraz obrambe pravoslavnega nauka, temveč tudi kot posledico neskladja med želenim in stvarnim stanjem oziroma kot nasprotovanje nekemu določenemu vidiku ravnanja staroruske politične elite, ki ji je po mnenju kijevskih metropolitov grozila nevarnost duhovno-konfesionalne brezbrižnosti (Danilevskij 2018, 126-128; Colucci 1988/1989, 585-586). Zlasti gornji trije primeri, ki zadevajo odnos med najvišjo posvetno in cerkveno oblastjo, pričujejo o tem, da so posvetni vrhovi staroruske družbe delovali pragmatično in jih zato verske razlike niso ovirale pri sklepanju politično koristnih (dinastičnih) vezi s katoliškimi vladarskimi rodbinami. Na podlagi dejstva, da se cerkvena pričakovanja glede verske »čistosti« niso uresničila, je mogoče sklepati še, da pravoslavna Cerkev v Kijevski Rusiji kljub svoji pomembni družbeni vlogi ni imela neomejenega vpliva.

\section{Sklep}

Glede na pričakovanja te literarne zvrsti ni potopis igumana Danijela prvenstveno usmerjen k predstavljanju družbene stvarnosti katoliško-pravoslavnih odnosov v Palestini; največ pozornosti namenja duhovnim razsežnostim romanja, v danem 
primeru tematizaciji simbolnega vstopa Kijevske Rusije v proces zgodovine odrešenja na ozemlju Svete dežele s preseganjem svojih lastnih geografskih in kulturnih meja. Od tod Danijelov pogled nase in na svojega konfesionalnega oziroma katoliškega »drugega« opredeljuje prepričanje, da je romanje opravil v imenu svoje domovine, »Ruske zemlje«. Pri potopiščevem dojemanju »drugega« izstopata dva vidika: naklonjeni odnos do kralja Balduina in hvaljenje frankovske skrbi za svete kraje. V skladu z opravljeno zgodovinsko in teološko analizo Romanja je katoliško-pravoslavne odnose v Jeruzalemskem kraljestvu mogoče opredeliti kot dvoumne: po eni strani je očitna jasna ločitev med »pravovernimi« in »Latinci«, po drugi pa je opazno strpno sobivanje pri ohranjanju spomina na kraje, povezane z biblijskimi dogodki. Igumanovega potopisa ni mogoče imeti za osamljeno pričevanje ali neko določeno posebnost, saj v njem svojevrstno odsevajo politične in kulturne okoliščine v takratni Kijevski Rusiji, ki so pogojevale odnos staroruske elite do katoliške Cerkve. Tudi tukaj je mogoče opaziti dvoumno stanje: na deklarativni ravni polemični spisi kijevskih metropolitov grškega oziroma bizantinskega izvora pričujejo o negativnem stališču do »latinskih herezij« in liturgičnih praks, po drugi strani pa odločitve staroruskih knezov potrjujejo njihovo pragmatično voljo po sodelovanju s sosednjimi katoliškimi političnimi tvorbami (Švedska, Poljska, Ogrska) pri oblikovanju dinastičnih porok in vojaških zavezništev. Na podlagi dejstva, da se cerkvena pričakovanja glede verske »čistosti« niso uresničila, je med drugim mogoče sklepati, da pravoslavna Cerkev v Kijevski Rusiji kljub svoji pomembni družbeni vlogi ni imela neomejenega vpliva.

\section{Reference}

Bogataj, Jan D. 2018. Neopatristična sinteza in ressourcement: med tradicijo in postmoderno. Bogoslovni vestnik 78, št. 4:957-969.

Chadwick, Henry. 2003. East and West: The Making of a Rift in the Church. Oxford: Oxford University Press.

Colucci, Michele. 1988/1989. The Image of Western Christianity in the Culture of Kievan Rus'. Harvard Ukrainian Studies 12/13:576-586.

Danilevskij, Igor' N. 2018. Antilatinskaja polemika na Rusi v XI-XII vekah. V: Colloquia Russica 8: Religions and Beliefs of Rus' (9th-16th Centuries), 115-129. Ur. Vitaliy Nagirnyy. Krakov: Uniwersytet Jagielloński.

Gardzaniti, Marčelo. 2007. U istokov palomničeskoj literatury Drevnej Rusi: »Hoženie« igumena Daniila v Svjatuju zemlju. V: »Hoženie» igumena Daniila v Svjatuju Zemlju v načale XII v., 270-338. Ur. Gelian M. Prohorov. Sankt Peterburg: Izdatel'stvo Olega Abyško.

Garzaniti, Marcello, ur. 1991. Itinerario in Terra santa. Rim: Città Nuova Editrice.

Klun, Branko. 2016. Marionovo razlikovanje med malikom in ikono in vprašanje hermenevtike. Bogoslovni vestnik 76, št. 1:25-35.

Levčenko, Mitrofan V. 1956. Očerki po istorii russko-vizantijskih otnošenij. Moskva: Akademija nauk SSSR.

Lotman, Jurij M. 2006. Znotraj mislečih svetov: Človek - tekst-semiosfera-zgodovina. Prev. Urša Zabukovec. Ljubljana: Studia humanitatis.

MacEvitt, Christopher H. 2008. The Crusades and the Christian World of the East: Rough Tolerance. Philadelphia: University of Pennsylvania Press. https://doi.org/10.9783/9780812202694

Malmenvall, Simon. 2018a. Pojem zgodovine odrešenja: pomen in idejni razvoj. Res novae 3, št. 2:39-58.

- - . 2018b. Pravna in ekonomska ureditev pravoslavne Cerkve v Kijevski Rusiji. Res novae 3, št. 1:25-43.

- - . 2017a. Beseda o postavi in milosti metropolita Hilarijona kot primer osmišljanja preteklosti v Kijevski Rusiji. Zgodovinski časopis 71, št. 1/2:8-29.

- - - 2017b. Narativni teksti o Borisu in Glebu 
med posredovanjem političnega zgleda in tolmačenjem zgodovine. Slavistična revija 70 , št. 2:312-322.

- - - 2015. Kijevska Rusija in Pripoved o minulih letih. V: Pripoved o minulih letih, 175-239. Ur. Blaž Podlesnik. Ljubljana: Znanstvena založba Filozofske fakultete.

Meyendorff, John. 1983. Byzantine Theology: Historical Trends and Doctrinal Themes. New York: Fordham University Press.

Nazarenko, Aleksandr V. 2001. Drevnjaja Rus' na meždunarodnyh putjah: Meždisciplinarnye očerki kul'turnyh, torgovyh, političeskih svjazej IX-XII vekov. Moskva: Jazyki russkoj kul'tury.

Osredkar, Mari J. 2018. V začetku je bil dialog. Bogoslovni vestnik 78, št. 1:17-31.

- - . 2016a. Darovanje kot najintenzivnejša oblika odnosa. Bogoslovni vestnik 76, št. 2:265-276.

- - . 2016b. Krščanski dialog v medčloveških odnosih. Edinost in dialog 71, št. 1/2:13-25.

Ostrowski, Donald. 2011. Pagan Past and Christian Identity in the Primary Chronicle. V: Historical Narratives and Christian Identity on a European Periphery: Early History Writing in Northern, East-Central, and Eastern Europe (c. 1070-1200), 229-253. Ur. Ildar H. Garipzanov. Turnhout: Brepols. https://doi.org/10.1484/m. tcne-eb.3.5026

Podskal'ski, Gerhard. 1996. Hristianstvo i bogoslovskaja literatura v Kievskoj Rusi (988-1237 gg.). Prev. Aleksandr V. Nazarenko. Sankt Peterburg: Vizantinorossika.

Popov, Andrej N. 1875. Istoriko-literaturnyj obzor drevnerusskih polemičeskih sočinenij protiv Latinjan XI-XV vekov. Moskva: Tipografija T. Ris.

Prohorov, Gelian M., ur. 2007a. "Hoženie» igumena Daniila v Svjatuju Zemlju v načale XII veka. Sankt Peterburg: Izdatel'stvo Olega Abyško.

- - - 2007b. Igumen Daniil i ego »Hoženie« v Svjatuju zemlju. V: »Hoženie« igumena Daniila v Svjatuju Zemlju v načale XII veka, 5-13. Ur. Gelian M. Prohorov. Sankt Peterburg: Izdatel'stvo Olega Abyško.
Raffensperger, Christian. 2012. Reimagining Europe: Kievan Rus' in the Medieval World. Cambridge MA: Harvard University Press.

Riley-Smith, Jonathan. 2005. The Crusades: A History. London: Continuum.

Runciman, Steven. 1990. A History of the Crusades: The Kingdom of Jerusalem and the Frankish East 1100-1187. Harmondsworth: Penguin Books.

Ryčka, Volodymyr. 2005. „Kyjiv-Drugyj Jerusalim» (z istoriji polytyčnoji dumky ta ideologiji seredn'ovičnoji Rusi). Kijev: Institut istoriji Ukrajiny.

Schulze, Hagen. 2003. Država in nacija v evropski zgodovini. Prev. Alenka Mercina. Ljubljana: Založba *cf.

Seemann, Klaus D. 1976. Die altrussische Wallfahrtsliteratur: Theorie und Geschichte eines literarischen Genres. München: Fink.

Seemann, Klaus D., ur. 1970. Choženie / Wallfahrtsbericht. München: Fink.

Senyk, Sophia. 1993. A History of the Church in Ukraine: To the End of the Thirteenth Century. Rim: Pontificio Istituto orientale.

Siecienski, Edward A. 2013. The Filioque: History of a Doctrinal Controversy. New York: Oxford University Press.

Tachiaos, Anthony-Emil N. 1988/1989. The Greek Metropolitans of Kievan Rus': An Evaluation of Their Spiritual and Cultural Activity. Harvard Ukrainian Studies 12/13:430-445. 